\title{
Pendampingan Penyusunan Media Pembelajaran Digibook (Buku Digital) di SDN Girimoyo 2 Kabupaten Malang
}

\author{
Erna Yayuk ${ }^{1}$, Kuncahyono ${ }^{2}$, Arina Restian ${ }^{3}$ \\ ${ }^{1,2,3}$ Prodi Pendidikan Guru Sekolah Dasar Universitas Muhammadiyah Malang \\ 1 er_2y@yahoo.co.id \\ ${ }^{2}$ kunpgsd@gmail.com \\ 3 arina.poenya@gmail.com
}

\begin{abstract}
ABSTRAK
Digibook merupakan buku digital yang mempunyai akses dalam mendapatkan informasi, memiliki fasilitas yang dapat membuat belajar lebih menarik, visual dan interaktif. Kegiatan ini melibatkan kerjasama dengan sekolah mitra. Terdapat 1 sekolah yang terlibat dalam kegiatan ini yaitu SDN Girimoyo 2 Kabupaten Malang. Untuk mensukseskan kemitraan ini guru yang akan menjadi peserta pelatihan perlu mendapatkan penguatan konsep, materi media pembelajaran, dan pengalaman baru dalam mengembangkan media berbasis teknologi sebagai penunjang dalam melakukan kegiatan pembelajaran di kelas secara optimal. Metode pelaksanaan dalam kegiatan ini yaitu workshop pelatihan, pendampingan, dan implementasi media digibook. Kegiatan selanjutnya pendampingan dalam pembuatan digibook (buku digital). Pendampingan dilakukan dalam rangka pembuatan produk media digibook (buku digital). Setiap guru akan mendapat pendampingan langsung dari tim. Dalam kegiatan pendampingan ini guru-guru didampingi sehingga guru-guru secara langsung mampu memproduksi produk digibook (buku digital) sesuai dengan materi yang diajarkan. Hasil akhir menunjukkan sebagai bentuk finishing dari pembuatan media digibook yaitu produk media digibook dan Impementasi media digibook (buku digital) pada pembelajaran. Guru-guru dapat mengimplementasikan produk digibook (buku digital) yang telah dibuat pada tahap sebelumnya dan direalisasikan dalam kegiatan pembelajaran. Tim pendamping bertindak sebagai observer yang akan mengamati dan memberikan resolusi terkait penerapan media digibook (buku digital) pada pembelajaran di kelas.
\end{abstract}

Kata Kunci: Pendampingan, Media Pembelajaran, digibook (buku digital)

\section{PENDAHULUAN}

SDN Girimoyo 2 Kabupaten Malang memiliki SDM diantaranya guru-guru dan tenaga kependidikan. Guru-guru yang ada di Sekolah tersebut adalah guru-guru yang notabennya adalah guru-guru yang berjumlah sedikit dan sudah berusia 50 tahun ke atas, jumlah guru tetap yang ada adalah 8 orang dan yang tidak tetap ada 4 guru. Berdasarkan fasilitas yang terdapat di sekolah tersebut masih perlu mendapat perhatian, dilihat dari beberapa kelas yang kurang kondusif penyebab dari minimnya prestasi yang diraih oleh siswa. Melihat kondisi tersebut perlu diperhatikan karena para guru tersebut mengajar tidak bisa maksimal dalam proses pembelajaran karena terbatasnya tenaga pendidik untuk SDN Girimoyo 2 Malang diatasi dengan cara merekrut guru kontrak atau guru honorer.

Melihat kondisi di atas, kualitas SDM maupun sarana dan prasarana yang ada di Sekolah SDN Girimoyo 2 Malang dirasa belum memadai dan belum optimal. Sedangkan di era globalisasi ini, guru sangat dituntut meningkatkan profesionalitasnya sebagai pengajar dan pendidik. Guru sebagai masyarakat sekolah harus melek teknologi. Perkembangan teknologi dapat menjadi salah satu alternatif dalam pemanfaatannya di bidang pendidikan. Peran teknologi dapat menjadi fasilitas dalam aktivitas pendidikan terutama dalam pembelajaran. Hal ini merupakan ciri dari gambaran abad 21. Oleh karena itu, sebagai sikap proaktif dari gambaran diatas, dosen PGSD Universitas Muhammadiyah Malang memandang perlu diadakan upaya pelatihan terhadap guru-guru salah satunya dengan berinovasi menciptakan media pembelajaran berbasis multimedia. Salah satu media pembelajaran yang berbasis multimedia adalah digibook.

Digibook merupakan buku digital yang mempunyai kecepatan dalam mendapatkan informasi, memiliki fasilitas 
yang dapat membuat belajar lebih menarik, visual dan interaktif. Berdasarkan kondisi yang telah dipaparkan, maka sangat diperlukan suatu kegiatan pendampingan untuk pembuatan perangkat pembelajaran khususnya media pembelajaran dengan memanfaatkan fasilitas teknologi yaitu digibook.

Berdasarkan analisis situasi dan kondisi empiris yang telah dipaparkan pada latar belakang yang dialami oleh guru-guru di SDN Girimoyo 2 Malang Kecamatan Karangploso Kabupaten Malang adalah: belum adanya pemanfaatan teknologi dalam pembelajaran, belum adanya media pembelajaran berbasis teknologi, dan belum dimilikinya kemampuan untuk menyusun/ mengembangkan media pembelajaran berbasis teknologi. Berdasarkan identifikasi permasalahan tersebut, maka perlu dilakukan pendampingan pembuatan media pembelajaran khususnya digibook (buku digital) serta implementasinya dalam pembelajaran.

$\mathrm{I}_{b} \mathrm{M}$ merupakan suatu program yang mencoba dan mengatasi kendala yang ada. Melalui pendampingan langsung pembuatan media pembelajaran khususnya digibook (buku digital)akan sangat membantu peningkatan kualitas pembelajaran di sekolah dasar Sekolah SDN Girimoyo 2 Malang.

\section{METODE KEGIATAN}

Secara umum pelaksanaan kegiatan pendampingan secara intensif dilakukan dengan tahapan sebagai berikut:

1. Workshop dan pelatihan pembuatan media digibook (buku digital) dalam pembelajaran Pada kegiatan workshop, para peserta mulai dari guru kelas I, II, III, IV, V, dan VI akan mendapatkan materi workshop dan pelatihan dari pemateri. Dalam kegiatan ini para peserta diharapkan akan meningkatkan pengetahuannya terkait pengembangan media, dan cara pembuatan media digibook (buku digital). Media yang dikembangkan dengan memanfaatkan Software yang dapat diunduh di internet.

2. Pendampingan pembuatan media digibook (buku digital). Guru-guru SD di SekolahSDN Girimoyo 2 Malang akan mendapatkan pendampingan dalam pembuatan digibook (buku digital). Pendampingan akan dilakukan dalam rangka pembuatan produk media digibook (buku digital). Pendampingan pembuatan digibook (buku digital) tidak hanya terbatas kepada kegiatan tatap muka secara konvensional tetapi juga dapat dilakukan melalui kegiatan berbasis online. Setiap guru akan mendapat pendampingan langsung dari tim. Dalam kegiatan pendampingan ini menggunakan form pendampingan untuk pembuatan dan mengembangkan produk digibook (buku digital).

3. Impementasi media digibook (buku digital) pada pembelajaran. Pada tahap ini, guru-guru akanmengimplementasikanproduk digibook (buku digital) yang telah dibuat pada tahap sebelumnya dan direalisasikan dalam kegiatan pembelajaran. Tim pendamping bertindak sebagai observer yang akan mengamati penerapan media digibook (buku digital) pada pembelajaran di kelas. Dalam kegiatan di kelas ini, kegiatan pembelajaran diobservasi.

4. Refleksi dan Tindak Lanjut

Kegiatan ini merupakan refleksi dari implementasi penerapan media digibook (buku digital) dalam pembelajaran di kelas. Catatancatatan perbaikan akan didiskusikan bersamasehingga dapat dijadikan rujukan untuk menyempurnakan produk media digibook (buku digital) yang telah dibuat serta perbaikan dalam pelaksanaan pembelajaran dengan menggunakan media.

\section{HASIL \& PEMBAHASAN}

1. Workshop dan pelatihan pembuatan media digibook (buku digital)

Pelaksanaan workshop pembuatan media digibook (buku digital) dilaksanakan di SDN Girimoyo 2 Kabupaten Malang pada tanggal 25 Maret 2017. Pelaksanaan workshop dilakukan selama sehari bersama tim pengabdian masyarakat yang terdiri atas 3 orang dosen PGSD FKIP UMM Ketiga dosen tersebut hadir untuk mengisi kegiatan Workshop dan pelatihan pembuatan media digibook. Kegiatan ini diikuti oleh guru-guru SD Girimoyo 2 Kabupaten Malang. Kegiatan workshop yang dilakukan bertujuan untuk memberikan pemahaman terkait materi pengembangan bahan ajar media berbasis IT. Penggunaan media pembelajaran berbasis teknologi perlu dilakukan di sekolah tingkat sekolah dasar terutama SDN Girimoyo 2. Hal ini dikarenakan mengingat SDM di SD tersebut tingkat pemahaman IT masih kurang dan dirasa perlu mendapat pelatihan terkait pengembangan media berbasis teknologi. Lebih lanjut berdasarkan fakta lapangan kondisi pembelajaran yang terjadi masih menggunakan buku tanpa ada media pendukung yang mampu memvisualisasikan materi secara utuh. 
Kepada guru-guru yang terlibat, melalui workshop ini diharapkan guru-guru memiliki pemahaman dan kompetensi dalam mengajar menggunakan media berbasis teknologi yaitu dengan menggunakan media digibook (buku digital). Kepala sekolah juga diharapkan menjadi fasilitator dan motivator sehingga guru-guru memahami dan mau mengimplementasikan media digibook (buku digital) dalam pembelajaran. Sehingga berdampak pada kemampuan guru terutama kemampuan menggunakan dan memproduksi media berbasis teknologi.

Kegiatan yang dilakukan oleh tim dosen pertama-tama mempersiapkan topik dan materi worksop dengan membagi menjadi 3 sesi. Sesi 1 yaitu penyampaian materi I oleh Erna Yayuk tentang Pengembangan media dan sumber belajar. Materi ke 2 disampaikan oleh Kuncahyono tentang cara pembuatan media digibook (buku digital). Sesi 3 merupakan FGD (Focus Group Discussion) yang dipandu oleh 3 orang pemateri sekaligus sesi tanyajawab untuk berbagi pengalaman, kesulitan, dan kemudahan dalam pembuatan digibook. Melalui kegiatan ini guru-guru terlibat langsung dan memiliki pengalaman nyata dalam mengembangkan dan membuat media digibook. Melalui cara ini guru-guru juga memahami bahwa media digibook merupakan media yang mengintegrasikan teknologi yang dapat digunakan dalam pembelajaran di kelas.

Berdasarkan hasil workshop yang sudah dilakukan oleh tim pengabdian, manfaat yang dirasakan oleh guru-guru yaitu 1) guruguru memiliki pengalaman baru terkait media berbasis teknologi bebrbentuk digibook yang selama ini belum dikenal bahkan sama sekali belum diterapkan dalam pembelajaran, 2) guru-guru memiliki keterampilan baru terutama dalam mendesain media digital yang berbasis teknologi, 3) keterampilan guru dalam mengimplemntasikan teknologi semakin meningkat, dan 4) inovasi baru dalam media pembelajaran yang dapat digunakan guru untuk menyusun materi dengan mengintegrasikan teknologi.

Materi yang kedua lebih banyak membahas secara detail bagaimana cara membuat dan mengembangkan media digibook yang dapat diaplikasikan menggunakan PC atau laptop. Penjelasan terkait langkah-langkah membuat digibook disajikan secara urut mulai dari pengenalan software/aplikasi dekstop author, cara menambah file berupa teks, video, suara, dan animasi yang dapat diintegrasikan dalam media digibook. Kegiatan yang berjalan mulai awal hingga akhir kegiatan memperlihatkan respon yang baik dari peserta, mereka tidak enggan untuk bertanya ketika belum memahami tentang materi dan bagaimana pembuatan digibook (buku digital).

\section{Pendampingan Pembuatan Media Digibook (buku digital)}

Kegiatan selanjutnya dari tindak lanjut workshop adalah melakukan pendampingan dalam pembuatan digibook. Selama proses pembuatan media digibook guru-guru mendapat bimbingan/pendampingan secara maksimal. Tim pendapingan terdiri atas 3 Dosen, yang bertugas mendampingi dan mengarahkan langkah-langkah dalam membuat media digibook. Guru-guru merancang media sesuai dengan materi pada kelas yang diajarkan. Kegiatan pendampingan yang dilakukan oleh tim pengadian dijadwalkan sesuai dengan kesepakatan antara pihak sekolah dan tim pengabdian. Adapun pelaksanaan pengabdian dilakukan sebanyak dua kali pendampingan. Berikut rincian kegiatan pendampingan yang dilakukan oleh tim pengabdian;

\section{Pendampingan ke 1}

Tahap pendampingan pertama dilakukan pada hari sabtu tanggal 8 April 2017. Pelaksanaan pendampingan berfokus pada teknik dalam merancang materi/layout media, menyusun media dan pengenalan aplikasi pembuat digibook. Adapun hasil kemajuan dari peserta pendampingan sebagai berikut:

\section{a. Guru kelas IV}

Materi atau bahan yang dirancang dalam media digibook pada kelas IV yaitu sebagai berikut:

Kompetensi Dasar

9.2 Mendeskripskan posisi bulan dankenampakan benda langit dari hari ke hari Materi : Benda langit

Indikator:

5. Mengidentifikasi kedudukan benda langit, misalnya mengamati penampakan benda benda langit, waktu dan posisi matahari terbit dan tenggelam, dan penampakan bulan dari hari ke hari

6. Mencari informasi tentang kedudukan benda langit

Berdasarkan kompetensi tersebut guru Kelas IV mmerancang materi terkait Benda langit. Materi diawali dengan pemandangan langit pada pagi dan sore hari. Pemandangan langit pada pagi hari terlihat benda langit matahari terbit, sedangkan pada sore hari 
terlihat matahari terbenam. Materi selanjutnya berupa pemandangan langit pada malam hari. Pada bagian ini dijelaskan materi bintang, bulan dan bentuk-bentuk bulan. Materi yang tersaji dalam digibook yang sudah dikembangkan oleh guru kelas IV dilengkapi dengan gambar sebagai penjelas informasi.

\section{b. Guru Kelas V}

Materi atau bahan yang dirancang dalam media digibook pada kelas IV yaitu sebagai berikut:

Kompetensi Dasar

7.1 Mendeskripsikan proses pembentukan tanah karena pelapukan

Materi: Jenis-jenis Batuan

Indikator:

1. Menggolongkan batuan berdasarkan warna, kekerasan, permukaan (kasar dan halus)

Berdasarkan kompetensi tersebut guru Kelas V merancang materi terkait jenis-jenis batuan. Pada bagian ini materi yang tersaji dalam digibook yang sudah dikembangkan oleh guru kelas $\mathrm{V}$ dilengkapi dengan gambar sebagai penjelas informasi.

\section{c. Guru Kelas VI}

Materi atau bahan yang dirancang dalam media digibook pada kelas IV yaitu sebagai berikut:

Kompetensi Dasar :

2.3 Mengidentifikasi cara perkembangbiakan tumbuhan dan hewan

Materi: Daur Hidup perkembangbiakan hewan Indikator

1. Mendeskripsikan daur hidup hewan

2. Mengidentifikasi daur hidup hewan

Berdasarkan kompetensi tersebut guru Kelas VI merancang materi terkait daur hidup hewan. Materi yang disajikan dengan memaparkan materi tentang pengertian metamorfosis kemudian dilanjutkan dengan materi jenis-jenis metamorfois beserta contoh hewan yang mengalami. Media digibook yang dikembangkan oleh guru kelas selain dilengkapi dengan gambar juga ditambahkan video untuk memperjelas materi.

\section{Pendampingan ke 2}

Tahap pendampingan kedua dilakukan pada hari sabtu tanggal 22 April 2017. Pada tahap pendampingan selain melalui bertatap muka secara langsung. Tim pengabdian juga memberikan falisitas secara online jika ada yang kurang dimengerti oleh guru-guru. Pendampingan tahap ke dua ini dilakukan untuk mengetahui perkembangan hasil produk digibook. Tindak lanjut Digibook yang sudah dihasilkan kemudian dipresentasikan secara bergantian dalam kegiatan FGD (focus Group Discussion). Hasil digibook yang dipresentasikan diberi masukkan atau saran oleh tim pengabdian agar digibook yang dihasilkan semakin sempurna dan layak untuk diaplikasikan dalam pembelajaran.

\section{Proses Pembelajaran Menggunakan Media digibook (buku digital)}

Untuk mengimplementasikan hasil produk digibook yang telah dibuat, maka tim pengabdian beserta guru-guru dan kepala sekolah SDN Girimoyo 2 bersepakat untuk mengadakan pembelajaran di kelas pada tanggal 24 Mei 2017. Implementasi digibook dilakukan di kelas V. Materi yang disajikan dalam pembelajaran menggunakan digibook ini yaitu tentang daur hidup hewan. Dalam proses pembelajaran tampak siswa merespon dengan baik, siswa senang belajar menggunakan media digibook karena media lebih menarik. Lebih lanjut berdasarkan paparan siswa kelas VI, siswa kelas VI lebih mudah memahami materi karena didukung oleh video sehingga materi yang diajarkan mudah untuk diingat.

Dalam proses pembelajaran menggunakan media digibook, tampak interaksi antara guru dan siswa sangat interaktif. Siswa-siswa menjawab pertanyaan yang diajukan oleh guru. Guru memberikan tanggapan positif berupa reward untuk meningkatkan semangat siswa dalam pembelajaran.

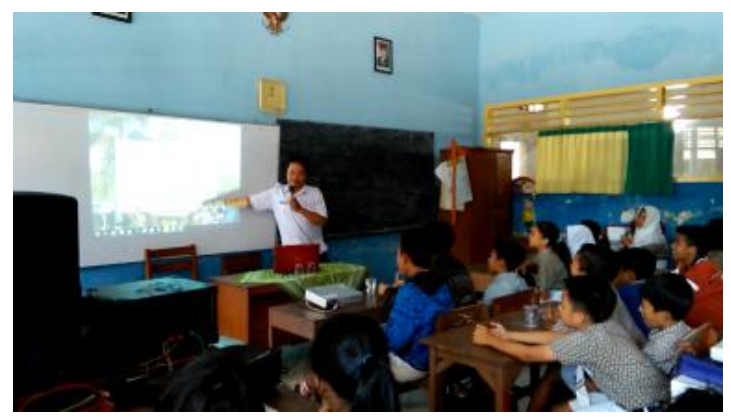

Gambar 1. Implementasi Digibook di kelas VI

Lebih lanjut berdasarkan gambar di atas pembelajaran berlangsung dengan adanya interaksi antara guru dan siswa. Terlihat guru melakukan interaksi kepada salah satu siswa terkait materi yang disampaikan menggunakan media digibook. Respon siswa menunjukkan bahwa siswa senang belajar menggunakan media, dan siswa lebih mudah memahami materi menggunakan media digibook. 


\section{Produk Media digibook}

Produk digibook yang sudah dihasilkan merupakan media yang berisi materi sesuai dengan kurikulum yang digunakan di SDN Girimoyo 2 Malang. Media juga berisi konsep materi yang diintegrasikan dengan multimedia yang bersifat interaktif. Dikatakan interaktif karena media berisi teks, suara, animasi, maupun video. Hal ini sejalan dengan pendapat Mishra (2005: 3) mendefinisikan multimedia interaktif adalah penyampaian informasi menggunakan teks, gambar, suara, animasi, dan video yang terorganisasi dalam suatu program.

Interaktif selanjutnya dari media digibook yang dihasilkan juga dapat diintegrasikan dengan link yang bisa diakses dengan media internet. Link yang dituju dapat diintegrasikan dengan alamat $u r l$ atau situs tertentu sebagai tambahan khasanah materi agar semakin luas. Hal ini didukung oleh Collins, (1997:3-4) menyatakan bahwa interaktif yaitu media yang digunakan dalam konteks pendidikan yang memadukan kaset video, audio, dan teks yang dikaitkan dengan teknologi seperti CDROM, CD-I (compact disc-interaktif) dan World Wide Web.

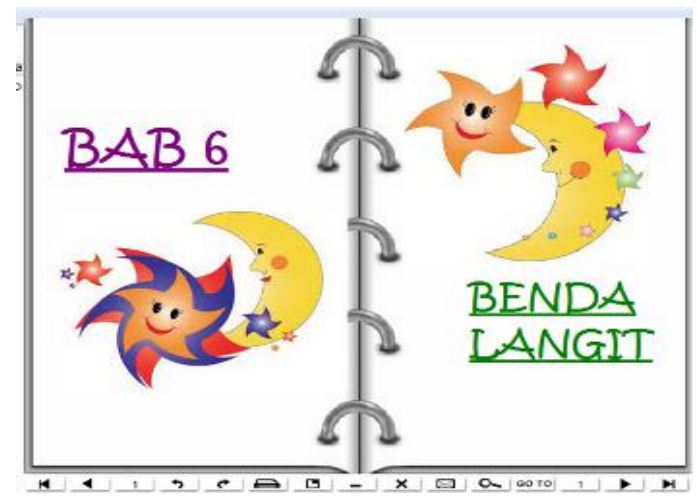

Gambar 2. Halaman awal digibook kelas IV

Produk digibook yang dihasilkan oleh guru kelas IV berisi materi tentang benda langit. Secara keseluruhan materi menjelaskan tentang matahari, bintang, dan bulan.

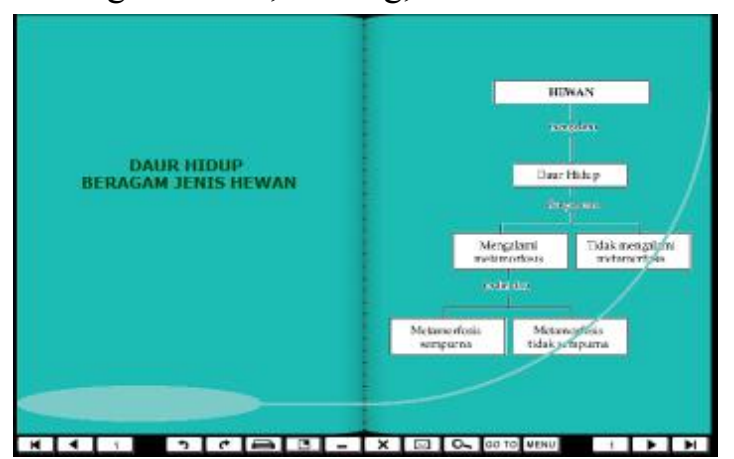

Gambar 3. Halaman awal tampilan digibook kelas VI
Produk digibook yang dihasilkan oleh guru kelas VI berisi materi Daur hidup hewan. Secara keseluruhan materi yang terdapat dalam media digibook berisi penjelasan tentang metamorfosis dan contoh hewan yang mengalami metamorfosis. Lebih lanjut produk digibook yang sudah dihasilkan oleh guru kelas VI ditunjang oleh multimedia yang berisi video terkait materi.

KESIMPULAN \& SARAN
Berdasarkan hasil pelatihan dan pendampingan yang sudah dicapai, maka kesimpulan dari pengabdian ini sebagai berikut: a. Hasil secara umum dari kegiatan pelatihan dan pendampingan yang dilakukan di SD Girimoyo 2 Kabupaten Malang berlangsung dengan baik dan maksimal. Kegiatan pelatihan menunjukkan hasil yang baik di mana guru-guru antusias mengikuti kegiatan dari awal sampai akhir. Berdasarkan hasil FGD guru-guru merasa senang karena mereka mendapat ilmu baru dan tentunya meningkatkan kompetensi guru di bidang teknologi terutama membuat media digibook. Lebih lanjut hasil pelatihan yang dilakukan oleh tim menunjukkan respon positif dari guru-guru dengan dibuktikan produk media digibook yang dihasilkan oleh guru-guru.

b. Pendampingan Pembuatan media digibook (buku digital). Pendampingan pembuatan digibook dilakukan sebanyak dua kali. Tim pendapingan terdiri atas 3 Dosen, yang bertugas mendampingi dan mengarahkan langkah-langkah dalam membuat media digibook. Guru-guru merancang media sesuai dengan materi pada kelas yang diajarkan. Kegiatan pendampingan yang dilakukan oleh tim pengadian dijadwalkan sesuai dengan kesepakatan antara pihak sekolah dan tim pengabdian

c. Penerapan Media Pembelajaran digibook (buku digital) di kelas

Hasil penerapan digibook dalam pembelajaran berjalan dengan baik. Materi yang disajikan dalam pembelajaran menggunakan digibook ini yaitu tentang daur hidup hewan. Dalam proses pembelajaran tampak siswa merespon dengan baik, siswa senang belajar menggunakan media digibook karena media lebih menarik.

d. Produk media digibook (buku digital). Produk media digibook yang sudah dihasilkan oleh guru-guru berupa materi Benda langit, daur hidup hewan, dan jenis- 
jenis batuan. Produk yang dihasilkan mendapat masukan terutama dari segi layout dan penataan content materi. Materi dapat ditambahkan multimedia berupa video atau suara untuk memperjelas konsep dan mempermudah pemahaman siswa.

Berikut ini beberapa saran yang diharapkan dapat membantu penelitian selanjutnya sebagai berikut:

a. Dalam melakukan pendampingan hendaknya lebih intensif dengan tambahan waktu, jika memungkinkan pendampingan dapat dilakukan secara tatap muka seara langsung untuk mengetahui kelebihan dan kekurangan produk digibook yang sudah dihasilkan oleh guru-guru

b. Bagi guru-guru dalam membuat digibook hendaknya dapat mengemas materi secara menarik dengan menambahkan animasi dan video.

Digibook yang sudah dibuat hendaknya diimplementasikan secara teratur dalam kegiatan pembelajaran agar keterampilan guru semakin meningkat.

\section{DAFTAR PUSTAKA}

Borg, W.R. \& Gall, M.D. 2003. Educational Research, An Introduction. Fourth Edition. New York: Longman

Budiningsih, A. 2004. Belajar dan Pembelajaran. Yogjakarta: Rineka Cipta Jakarta : BPP

Collins, J., Hammond, M., and Wellington, J. 1997. Teaching and Learning with Multimedia. London: Routledge

Kementerian Pendidikan dan Kebudayaan. (2013) Standar Nasional Pendidikan.

Mishra, S. \& Ramesh, C. Sharma. 2005.

Interactive Multimedia in Education

and Training. United States of

America: Idea Group Publishing (an imprint of Idea Group Inc.)

Undang-Undang Republik Indonesia, Nomor: 20 Tahun 2003 tentang Sisdiknas(Sistem Pendidikan Nasional), Penerbit Fokusmedia Bandung.

www.dekstopauthor.org

Slavin, Robert E. 2011. Educational Psychology: theory and practices. USA: Pearson Education. 